\title{
Thrombus aspiration during primary percutaneous coronary intervention - Where are we now?
}

\author{
Nemanja Milićević, Siniša Stojković, Vladimir Miloradović, Siniša Maksimović \\ $J Z U$ „SV Vračevi“ Bijeljina
}

Abstract

Introduction. thrombus aspiration is not recommended as a routine procedure considering the results of large randomised trials. It is necessary to define new indications for thrombus aspiration in myocardial infarction and to conduct appropriate trials.

The aim of this paper was to report a patient with succesfful aspiration of large thrombus mass from right coronary artery made after primary balloon angioplasty, and to consider which patients could benefit with this procedure.

Case report. a male, 80 years old, has been admitted to a catheterisation laboratory with clinical, biochemical and electrocardiographic signes of acute myocardial infarction with ST segment elevation (STEMI) of inferoposterolateral localisation along with sinus bradycardia and profound arterial hypotension, which all are characteristic for inferior myocardial wall infarction with right ventricular involvement. Two hours after pain onset the patient was admitted to hospital in Bjeljina and sent to catheterisation laborathory straight after. All branchies of left coronary artery were well visualized and without significant stenosis. Right coronary artery was occluded in proximal segment. Predilatation was performed with SC Sprinter legend 2,0x20mm balloon. After predilatation thrombus burden is still large, blood flow was slow with significante residual stenosis. Than, BMS Pro-kinetick energy $3,5 \times 20 \mathrm{~mm}$ stent was implanted. After stent implantation thrombus burden existed and there was no flow in PLV branch. Thrombus mass was $2 \mathrm{~cm}$ long and succesffully aspirated with Export aspiration catheter. Control coronarography showed no residual stenosis and normal blood flow was restored through branches of right coronary artery.

Conclusion. Procedure must be gradual, carefully planned and aspiration of thrombus should be taken only after initial balloon angioplasty with flow evaluation. Large thrombus burden or several smaller thrombi with clear flow obstruction and poor periferal flow could be the reason for aspiration of thrombus along with possible intracoronary administration of GP IIbllla inhibitors. If conducted cautiously, aspiration of thrombus may still be considered as a valuable techique in selected patients with a large angiographic thrombus burden.

Key words acute myocardial infarction STEMI, primary percutaneous coronary intervention, aspiration technique

\section{Introduction}

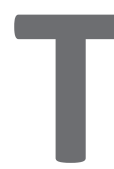

hrombus aspiration during primary percutaneous coronary intervention ( $\mathrm{pPCl}$ ) has been used to improve myocardial perfusion through a reduction of the thrombotic burden eventually resulting with better clinical outcomes. ${ }^{1,2}$ After the initial enthusiasm derived from the mortality reduction shown in early randomized and observational studies, ${ }^{3-7}$ disappointing results have been yielded in more recent larger scale trials testing the routine use of thrombus aspiration in $\mathrm{pPCl}{ }^{8-12}$ As a consequence, this technique has lost its initial appeal and currently is often neglected or even considered as a useless by the interventional cardiologists. The recent meta-analysis by Jolly et al. ${ }^{13}$ conducted in more than 18,000 patients once again reinforces the evidence that overall there is no benefit in the routine use of thrombus aspiration during $\mathrm{pPCl}$. However, it has the merit to shed light on the residual potential of this technique, which has probably been dismissed too quickly. First, there were no significant differences in the occurrence of cardiovascular events up to 1-year post-pPCl between patients treated conventionally versus those treated with routine adjunctive thrombus aspiration. Of interest, in the subgroup of patients with large angiographic thrombus burden (i.e., TIMI thrombus grade $\geq 3$ ), thrombus aspiration was associated with a significant reduction in cardiovascular death [ $2.5 \%$ vs. $3.1 \%$; hazard ratio $0.80,95 \%$ confidence interval $(\mathrm{Cl}), 0.65-0.98, \mathrm{P}=0.03$ ]. This meta-analysis in fact assessed data from the three largest randomized trials on this topic, namely Thrombus Aspiration during Percutaneous coronary intervention in Acute myocardial infarction Study (TAPAS), ${ }^{4,5}$ Thrombus Aspiration in ST elevation Myocardial Infarction in Scandinavia (TASTE) ${ }^{8,9}$ and 

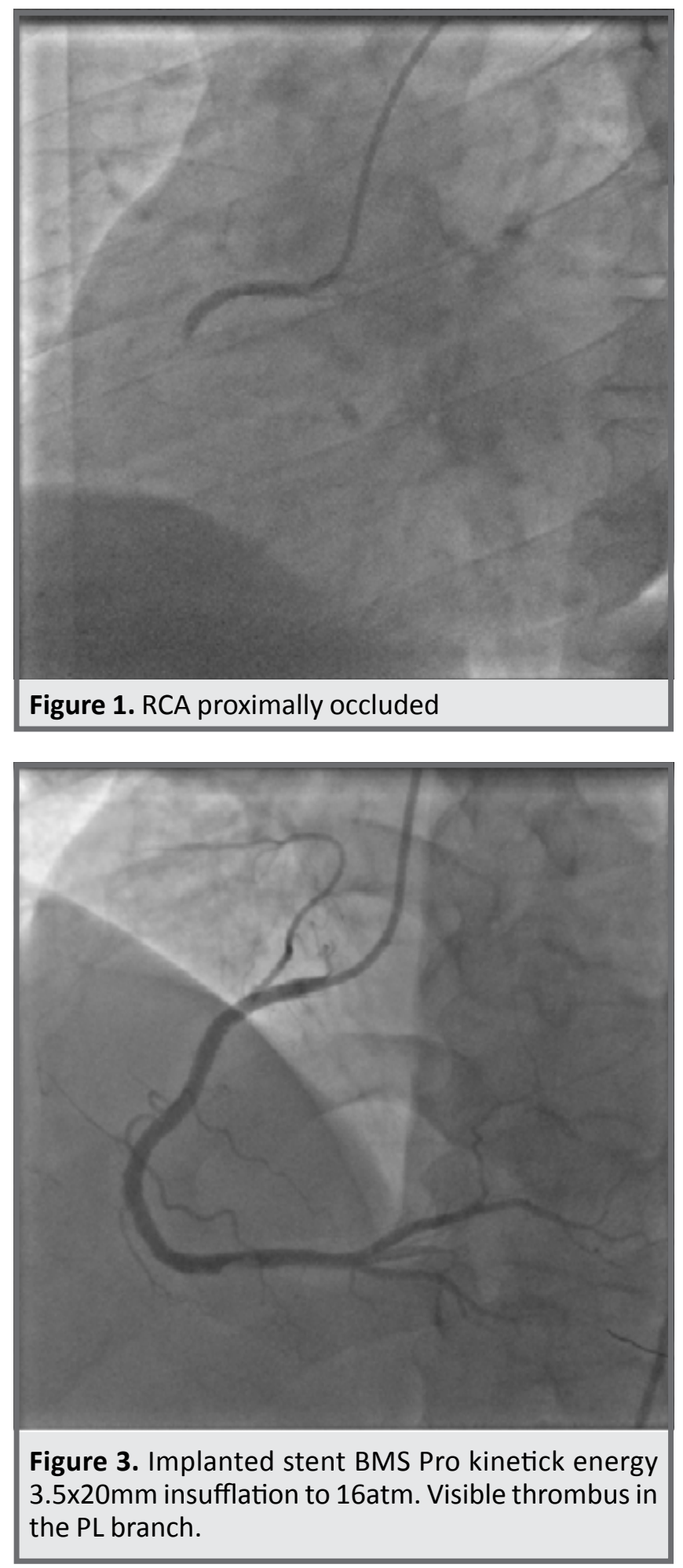

Thrombectomy with $\mathrm{PCl}$ versus $\mathrm{PCl}$ Alone in Patients with STEMI (TOTAL.) ${ }^{11,12}$ While in TAPAS and TOTAL patients were randomized to thrombus aspiration or conventional $\mathrm{PCl}$ prior to coronary angiography, in TASTE the randomization was performed after angiography, potentially introducing heterogeneity in coronary anatomy between the studies. Moreover, thrombus grade was evaluated before wire crossing in TAPAS and TOTAL and after wiring in TASTE. This explains the $74 \%$ rate of patients with thrombus grade 4 or 5 in TOTAL trial, whereas this rate was only $32 \%$ in TASTE. Other differences might concern the data collection (e.g., cerebrovascular accidents were not recorded in TAPAS, and no distinction reported be-

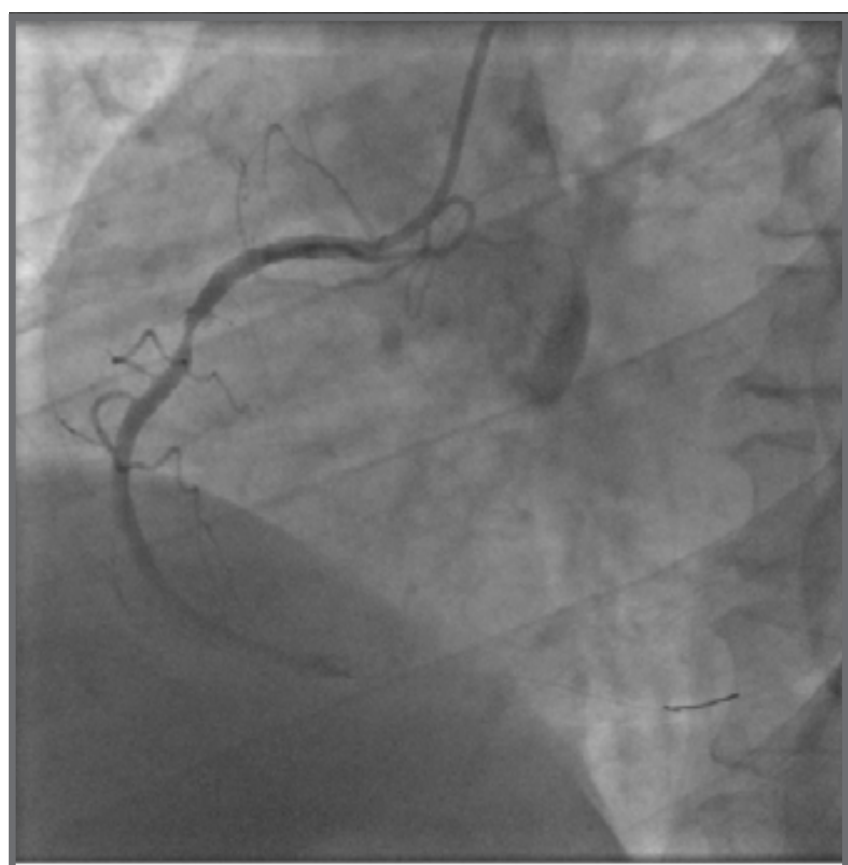

Figure 2. Recanalized RCA (BMW guidwire and predilatation balloon SC Sprinter legend 2,0×20mm insufflation to $16 \mathrm{~atm})$. Visible intracoronary thrombus distal in PL branch

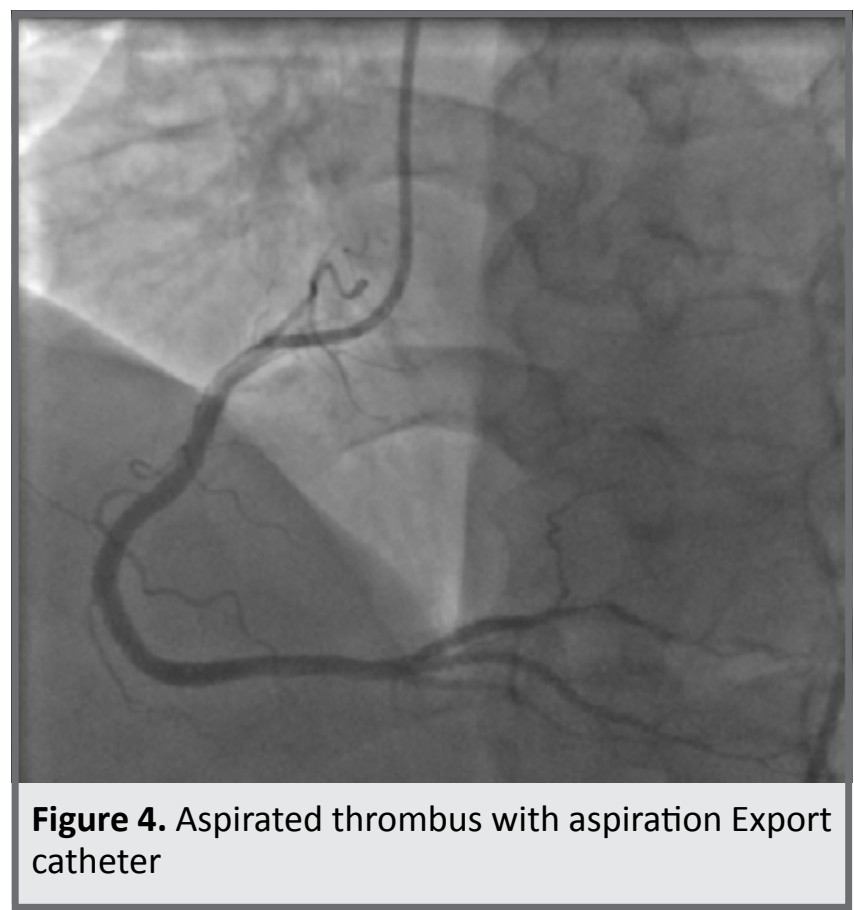

tween stroke or TIA in TASTE) and adjudication of clinical endpoints (independent adjudication in TAPAS and TASTE, monitoring as part of an institutional registry in TASTE). In addition, some differences between the two pooled groups of patients are worth mentioning. First, patients treated with thrombus aspiration showed a longer interval from symptom onset to hospital arrival (190 vs. $185.5 \mathrm{~min} ; \mathrm{P}=0.025)$. While this difference might seem to be trivial, on a larger scale pain-to-needle time is still considered as one of the major determinants of prognosis in STEMI patients. ${ }^{14}$ Furthermore, in the thrombus aspiration group a higher frequency of direct stenting (39.5\% vs. $21.1 \%, \mathrm{P}<0.001$ ) and lower use of glycoprotein Ilb/IIla 
inhibitors ( $32.3 \%$ vs. $35.1 \%, \mathrm{P}<0.001)$ was recorded. Thrombus aspiration has been consistently shown to affect procedural strategies in terms of balloon dilatation and stent selection. ${ }^{4,6,8,15,16}$ In particular, it is associated with higher rate of direct stenting, lower rate of post-dilatation, with the implantation of less stents but of larger size as compared with conventional $\mathrm{PCl}^{15,16}$. Whether these technical differences in $\mathrm{PCl}$ might have a substantial impact on clinical outcome is still controversial ${ }^{17,18}$. As to the use of glycoprotein Ilb/Illa, previous evidence suggested that thrombus aspiration is of particular benefit in patients treated with glycoprotein IIb/IIla inhibitors. ${ }^{19}$ Such synergistic effect was also confirmed by Pyxaras et $a l,^{20}$ where the combination of manual thrombus aspiration with intravenous abciximab resulted into a significantly lower incidence of adverse cardiovascular events at 1 year compared with the single strategies. In a small randomized study, intracoronary applied tirofiban combined with thrombus aspiration in STEMI patients undergoing $\mathrm{pPCl}$, was associated with improved angiographic and clinical outcomes compared with thrombus aspiration alone or conventional $\mathrm{PCl} .{ }^{21}$ Similar evidence derives from the Intracoronary Abciximab Infusion and Aspiration Thrombectomy in Patients Undergoing Percutaneous Coronary Intervention for Anterior ST Segment Elevation Myocardial Infarction (INFUSE-AMI) trial ${ }^{22}$ that showed in a post hoc analysis how median infarct size was lowest in the intracoronary abciximab plus aspiration group.The clinical benefit shown with thrombus aspiration in terms of decreased cardiovascular death in the subgroup of patients with large angiographic thrombus burden was partly offset by an increased rate of stroke or transient ischemic attack (TIA) (0.9\% vs. $0.5 \%$; odds ratio $1.56,95 \%$ $\mathrm{Cl}, 1.02-2.42 ; \mathrm{P}=0.04)$. The latter could be attributed to technical issues both operator- and device-related. These include catheter-induced embolization of the thrombus into the systemic vasculature, aggressive guiding catheter manipulation required to advance the aspiration catheter and displacing aortic atheroma, and longer procedure time resulting from the aspiration procedure..$^{23}$ The risk of systemic embolization can be reduced with improved technique. For instance, a thrombus that cannot be fully aspirated is at risk of fracturing and shedding fragments or entering still intact into the systemic vasculature, particularly if suction is not maintained in the aspiration catheter, and the guiding catheter is not engaged in the artery as the aspiration catheter is withdrawn. ${ }^{24}$

Interestingly, all three trials included in the meta-analysis only evaluated manual thrombus aspiration. While more complex (i.e., mechanical) devices might be more effective in extracting atherothrombotic particles from the coronary arteries, they are bulkier and require selected coronary anatomies. No consistent clinical benefit has been shown with these devices over $\mathrm{PCl}$ alone, ${ }^{19}$ however, potential benefits from these apparently more effective thrombectomy devices need to be tested in adequately powered ad hoc prospective studies.

\section{Case presentation}

A patient, male, 80 years old, has been admitted to a laboratory for a catheterization with clinical, bioche- mical and ECG signs of an acute myocardial infarction without ST elevation of an inferoposterolateral region, 2 hours after the occurrence of pain with clinical signs and symptoms of heart failure. TA: $80 / 60 \mathrm{mmHg}$, Killip IV. Non smokers, does not consume alcohol and without a disease of significance for heredity and chronicity.

Coronary angiography: LM proper deviate, direction, lumen without stenosis, is divided into LAD and LCX. LAD proper deviate, direction, lumen without stenosis. $L C x$ proper deviate, direction, lumen without stenosis. RCA: proper deviate, proximally occluded $100 \%$ (figure 1 ).

$\mathrm{pPCl}$ RCA: we set $\mathrm{SH}$ guiding catheter in the RCA ostium. $B M W$ coronary wire was placed in the periphery of the RCA. We performed predilatation occluded segment with balloon SC Sprinter legend 2,0x20 mm insufflation to 16atm, followed by establishing flow through the artery (figure 2). Implanted stents medial BMS Pro-kinetick energy $3,5 \times 20 \mathrm{~mm}$ insufflation to $16 \mathrm{~atm}$. (figure 3 ). On the control coronarography, a thrombus is seen in the direction of the PL branch which is successfully aspirated by the Export catheter (figure 5). Thereafter flow in all branches of TIMI III, without residual stenosis and without dissection (figure 4).

\section{Discussion}

The patient was admitted to the catheterization laboratory with clinical, biochemical and electrocardiographic signs of acute myocardial infarction with ST elevation of the inferoposterolateral region with sinus bradycardia, 2 hours after the onset of pain with clinical signs and symptoms of cardiac failure, TA: $80 / 60 \mathrm{mmHg}$, Killip IV. After the described intervention, the patient was hemodynamically stable, compensated with electrocardiographic signs of ischemia in inferior leads of ECG. The aim of the case is to indicate its significance in the primary $\mathrm{PCl}$ of acute myocardial infarction with ST elevation. Overall, the lesson derived from the metaanalysis by Jolly et al., and in general from the literature produced over the last 10 years and the case itself, is that performing thrombus aspiration routinely during $\mathrm{pPCl}$ does not result into substantial clinical benefit and in some situations, might be potentially harmful. However, thrombus aspiration if carefully performed may still be considered as a valuable technique in selected patients with large angiographic thrombotic burden.

\section{References}

1. Mahmoud KD, Zijlstra F. Thrombus aspiration in acute myocardial infarction. Nat Rev Cardiol 2016;13:418-28.

2. Higuma T, Soeda T, Yamada M, et al. Does Residual Thrombus After Aspiration Thrombectomy Affect the Outcome of Primary $\mathrm{PCl}$ in Patients With ST-Segment Elevation Myocardial Infarction?: An Optical Coherence Tomography Study. JACC Cardiovasc Interv 2016;9:2002-11.

3. Burzotta F, Trani C, Romagnoli E, et al. Manual thrombus-aspi= ration improves myocardial reperfusion: the randomized evaluation of the effect of mechanical reduction of distal embolization by thrombus-aspiration in primary and rescue angioplasty (REMEDIA) trial. J Am Coll Cardiol 2005;46:371-76.

4. Svilaas T, Vlaar PJ, van der Horst IC, et al. Thrombus aspiration during primary percutaneous coronary intervention. $\mathrm{N}$ Engl J Med2008;358:557-67.

5. Vlaar PJ, Svilaas T, van der Horst IC, et al. Cardiac death and reinfarction after 1 year in the Thrombus Aspiration during Percu- 
taneous coronary intervention in Acute myocardial infarction Study (TAPAS): a 1-year follow-up study. Lancet 2008;371:1915-1920.

6. Mangiacapra F, Wijns W, De Luca G, et al. Thrombus aspiration in primary percutaneous coronary intervention in high-risk patients with ST-elevation myocardial infarction: a real-world registry.Catheter Cardiovasc Interv 2010;76:70-76.

7. Sardella G, Mancone M, Canali E, et al. Impact of thrombectomy with EXPort Catheter in Infarct-Related Artery during Primary Percutaneous Coronary Intervention (EXPIRA Trial) on cardiac death. Am J Cardiol 2010;106:624-629.

8. Fröbert $\mathrm{O}$, Lagerqvist $\mathrm{B}$, Olivecrona GK, et al. Thrombus aspiration during ST-segment elevation myocardial infarction. N Engl J Med 2013;369:1587-1597.

9. Lagerqvist B, Fröbert O, Olivecrona GK, et al. Outcomes 1 year after thrombus aspiration for myocardial infarction. N Engl J Med2014;371:1111-1120.

10. Jones DA, Rathod KS, Gallagher S, et al. Manual Thrombus Aspiration Is Not Associated With Reduced Mortality in Patients Treated With Primary Percutaneous Coronary Intervention: An Observational Study of 10,929 Patients With ST-Segment Elevation Myocardial Infarction From the London Heart Attack Group. JACC Cardiovasc Interv 2015;8:575-584.

11. Jolly SS, Cairns JA, Yusuf S, et al. Randomized trial of primary PCI with or without routine manual thrombectomy. N Engl J Med 2015;372:1389-1398.

12. Jolly SS, Cairns JA, Yusuf S, et al. Outcomes after thrombus aspiration for ST elevation myocardial infarction: 1-year follow-up of the prospective randomised TOTAL trial. Lancet 2016; 387:127-135.

13. Jolly SS, James S, Džavík V, et al. Thrombus Aspiration in ST-Seg ment-Elevation Myocardial Infarction: An Individual Patient Meta-Analysis: Thrombectomy Trialists Collaboration. Circulation 2017;135:143-152.

14. Authors/Task FM , Windecker S, Kolh P, et al. 2014 ESC/EACTS Guidelines on myocardial revascularization: The Task Force on Myocardial Revascularization of the European Society of Cardiology (ESC) and the European Association for Cardio-Thoracic Surgery (EACTS)Developed with the special contribution of the European Association of Percutaneous Cardiovascular Interventions (EAPCI). Eur Heart J 2014;35:2541-2619.
15. Lemesle G, Sudre A, Bouallal R, et al. Impact of thrombus aspiration use and direct stenting on final myocardial blush score in patients presenting with ST-elevation myocardial infarction.Cardiovasc Revasc Med 2010;11:149-154.

16. Fernández-Rodríguez D, Regueiro A, Brugaletta $S$, et al. Optimization in stent implantation by manual thrombus aspiration in ST-segment-elevation myocardial infarction: findings from the EXAMINATION trial. Circ Cardiovasc Interv 2014;7:294-300.

17. McCormick LM, Brown AJ, Ring LS, et al. Direct stenting is an independent predictor of improved survival in patients undergoing primary percutaneous coronary intervention for ST elevation myocardial infarction. Eur Heart J Acute Cardiovasc Care2014;3:340-346.

18. Dudek D, Mielecki W, Burzotta F, et al. Thrombus aspiration followed by direct stenting: a novel strategy of primary percutaneous coronary intervention in ST-segment elevation myocardial infarction. Results of the Polish-Italian-Hungarian RAndomized ThrombEctomy Trial (PIHRATE Trial). Am Heart J2010;160:966-972.

19. Burzotta F, De Vita M, Gu YL, et al. Clinical impact of thrombectomy in acute ST-elevation myocardial infarction: an individual patient-data pooled analysis of 11 trials. Eur Heart J2009; 30: 2193-2203.

20. Pyxaras SA, Mangiacapra F, Verhamme K, et al. Synergistic effect of thrombus aspiration and abciximab in primary percutaneous coronary intervention. Catheter Cardiovasc Interv 2013;82:604-611.

21. Gao L, Cao Z, Zhang H. Efficacy and Safety of Thrombectomy Combined with Intracoronary Administration of Tirofiban in STsegment Elevation Myocardial Infarction (STEMI). Med Sci Monit 2016;22:2699-2705.

22. Stone GW, Maehara A, Witzenbichler B, et al. Intracoronary abciximab and aspiration thrombectomy in patients with large anterior myocardial infarction: the INFUSE-AMI randomized trial.JAMA 2012;307:1817-1826.

23. Jolly SS, Cairns JA, Yusuf S, et al. Stroke in the TOTAL trial: a randomized trial of routine thrombectomy vs. percutaneous coronary intervention alone in ST elevation myocardial infarction.Eur Heart J 2015;36:2364-2372.

24. Brown ED, Blankenship JC. A mechanism for stroke complicating thrombus aspiration. Catheter Cardiovasc Interv2017;89:93-96.

\section{Sažetak}

\section{Aspiracija tromba tokom primarne perkutane koronarne intervencije - gde smo sada?}

Nemanja Milićević, Siniša Stojković, Vladimir Miloradović, Siniša Maksimović

JZU „SV Vračevi“ Bijeljina

Uvod. Aspiracija tromba u akutnom infarktu miokarda, sobzirom na rezultate velikih randomizovanih studije se ne preporučuje kao rutinska metoda. Potrebno je definisati nove indikacije za tromboaspiraciju u infarktu miokarda i sprovesti odgovarajuće studije u tom pravcu.

Cilj ovog rada je da se prikaže bolesnik kod koga je nakon primarne balon angioplastike urađena uspešna aspiracija velike trombne mase iz desne koronarne arterije uz razmišljanje kod koji bolesnika bi ova metoda imala koristi.

Prikaz slučaja. Muškarac, životne dobi od 80 godina, primljen je u laboratoriju za keteterizaciju sa kliničkim, biohemijskim i elektrokardiografskim znacima infarkta miokarda sa ST elevacijom (STEMI) inferoposterolateralne lokalizacije uz sinusnu bradikardiju i tešku hipotenziju što karakteriše infarkte donjeg zida sa zahvatanjem desne komore. Dva sata nakon pojave bolova bolesnik je primljen u bolnicu u Bjeljini i odmah po prijemu je upućen u kateterizacionu salu. Sve grane leve koronarne arterije su dobro prikazane i na njima nije nađeno prisustvo značajnih stenoza. Desna koronarna arterija je bila visoko okludirana. Nakon postavljanja uvodnika u ostijum desne koronarne arterije, lako se prošlo kroz trombnu masu koronarnom BMW žicom u distalni deo arterije. Potom je učinjena predilatacija balonom SC Sprinter legend 2,0x20 $\mathrm{mm}$. Nakon predilatacije, trombno opterećenje je i dalje veliko, usporen je protok kroz arteriju uz značajnu rezidualnu stenozu. Potom je proksimalno na leziju gde je najveća stenoza implantiran stent BMS Pro-kinetick energy 3,5x20 $\mathrm{mm}$. Nakon implantacije stenta stenta bilo je i dalje prisutno veliko trombno opterećenje i nije bilo protoka u PLV grani, tako da je odlučeno da se uradi aspiracija tromba. Velika trombna masa dužine $2 \mathrm{~cm}$ je uspešno aspirirana aspiracionim Export kateterom. Na kontrolnoj koronarografiji nije bilo rezidualne stenoze uz normalan protok i kroz distalne grane desne koronarne arterije.

Zaključak. Procedura mora biti postupna, pažljivo planirana i da tek nakon inicijalne balon angioplastike uz procenu protoka, se treba pristupiti odluci o tromboaspiraciji. Velika trombna masa, ili više manjih trombnih masa uz jasnu obstrukciju protoka i lošiji protok na periferiji bi mogao biti razlog za trombospiraciju uz eventualnu intrakoronarnu primenu GP IIbllla inhibitora. Ako se pažljivo izvodi, aspiracija tromba se i dalje može smatrati dragocenom tehnikom kod odabranih pacijenata sa velikim angiografskim trombotičnim opterećenjem.

Ključne reči: akutni infarkt miokarda STEMI, primarna perkutana koronarna intervencija, aspiraciona tehnika 